\title{
DIFFERENTIAL SHEEP-CELL AGGLUTINATION TEST IN RHEUMATOID ARTHRITIS*
}

\author{
BY \\ ROBERT BROWN, JOSEPH J. BUNIM, AND CURRIER MCEWEN \\ From the Department of Medicine and the Study Group on Rheumatic Diseases, New York University \\ College of Medicine, and the Third Division of Bellevue Hospital, New York City
}

In March, 1948, Rose and others described a test for rheumatoid arthritis which depended on the ability of serum from patients with rheumatoid arthritis to agglutinate " sensitized " sheep erythrocytes in much higher titre than normal sheep erythrocytes. The authors reported results in 110 patients, of whom 27 had active rheumatoid arthritis and 16 inactive rheumatoid arthritis, 3 Still's disease, and 5 Marie-Strümpell arthritis : 59 were nonrheumatic controls. Only the patients with rheumatoid arthritis and related diseases showed an elevation of the agglutination titre for "sensitized" sheep cells. The authors reported that the active fraction was found in the beta gamma globulin fraction of electrophoretically separated serum.

Sulkin and others (1948) reported on 149 patients including 35 with active rheumatoid arthritis, 1 with Still's disease, and 7 with Marie-Strümpell spondylitis. Forty-six per cent. of these patients and none of the controls had a raised titre for agglutinins of " sensitized" sheep cells. The authors correlate the presence of a raised titre with greater severity and increased duration of the disease.

Jawetz and Hook (1949) reported the results of this test in 161 patients of whom 78 had rheumatoid arthritis. In this study 65 per cent. of the patients with markedly active rheumatoid arthritis and 13.5 per cent. of the group classified as mildly or moderately active had an elevation of the agglutination titre for "sensitized" sheep erythrocytes ; none of the inactive group had a raised titre. In the controls there were two patients, one with hepatitis and one with ankylosing spondylitis, who had a raised titre for the " sensitized" sheep cells.

Our report presents the results of the sheep-cell agglutination test performed on sera of 164 patients and 13 normal adult males. The cases studied included rheumatoid arthritis, and, as controls,

- This investigation was aided by a grant from the Masonic Foundation for Medical Research and Human Welfare. other rheumatic disorders and non-rheumatic diseases.

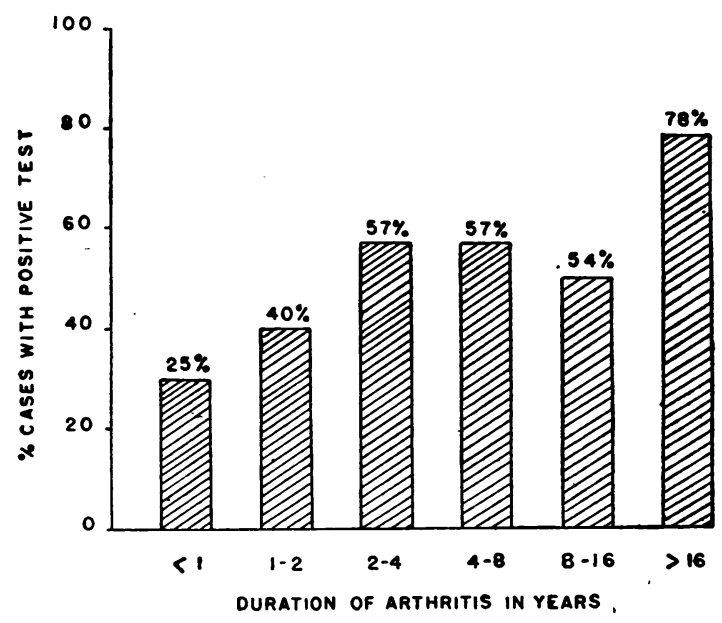

FIGURE.-Relation of incidence of positive tests to the duration of rheumatoid arthritis.

\section{Methods and Materials}

In these tests commercially preserved sheep erythrocytes and anti-sheep rabbit serum preserved with 50 per cent. glycerine were used.

As a preliminary test the rabbit serum was titrated against a 1 per cent. suspension of normal preserved sheep erythrocytes. Dilutions of the serum were made from $1: 100$ to $1: 1,000$ in saline in $0.5 \mathrm{ml}$. volume. To each of the ten tubes was added $0.5 \mathrm{ml}$. of a 1 per cent. sheep erythrocyte suspension in saline. The tubes were shaken, incubated for one hour at $37^{\circ} \mathrm{C}$., placed in the refrigerator overnight, and read the next morning for agglutination. Most of the lots of anti-sheep serum agglutinated the sheep erythrocytes to a final dilution of $1: 600$ or $1: 800$. In " sensitizing" the sheep cells for the agglutination test, the dilution of the rabbit serum used was twice that in the last tube which gave a $1+$ agglutination in the preliminary titration described above. At least ten minutes was allowed to elapse 
between the addition of the anti-sheep rabbit serum to the sheep cells and the addition of the sensitized sheep cells to the patient's serum.

The sera of patients were obtained from freshly drawn venous blood and inactivated by heating at $56^{\circ} \mathrm{C}$. for thirty minutes. Two twelve-tube series of serial twofold dilutions in $0.5 \mathrm{ml}$. volumes were prepared. To the first series of tubes $0.5 \mathrm{ml}$. of a 1 per cent. suspension of sensitized sheep erythrocytes, prepared in the manner described above, was added, and to the second series of tubes $0.5 \mathrm{ml}$. of a 1 per cent. suspension of normal sheep erythrocytes. Thus the final dilution of reagents in the first tube of the first series was: patient's serum, $1: 4$; sheep cells, 0.5 per cent. suspension ; anti-sheep rabbit serum, $1: 3,200$ if the titre in the preliminary titration of sheep cells against rabbit serum was $1: 800$.

The tubes were shaken and incubated at $37^{\circ} \mathrm{C}$. for one hour, then placed in a refrigerator overnight, and read the next morning for agglutination. A typical series of readings was as follows :

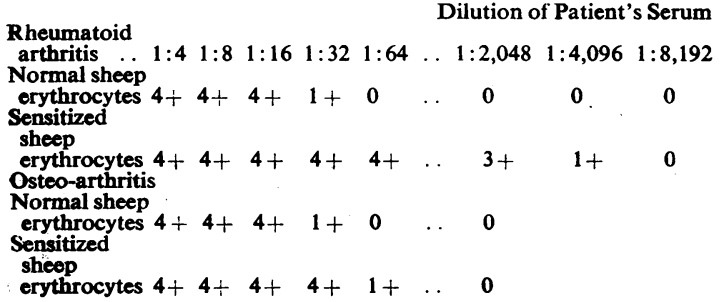

The results of the test are expressed as the quotient of titre of the "sensitized" sheep cells divided by the titre of the normal sheep cells. This is called the differential titre. Thus in the first example given above the differential titre would be 4,096 divided by 32 , or 128.

The haemolytic streptococcus agglutination titration was done against Griffith types 1 and 19 and Lancefield type 38 of group A haemolytic streptococci.* Stock cultures were kept in neopeptone rabbit blood broth,

TABLE 1

RESULTS OF TESTS FOR SHEEP CELL AGGLUTININS IN SERA OF 83 PATIENTS USED AS CONTROLS †

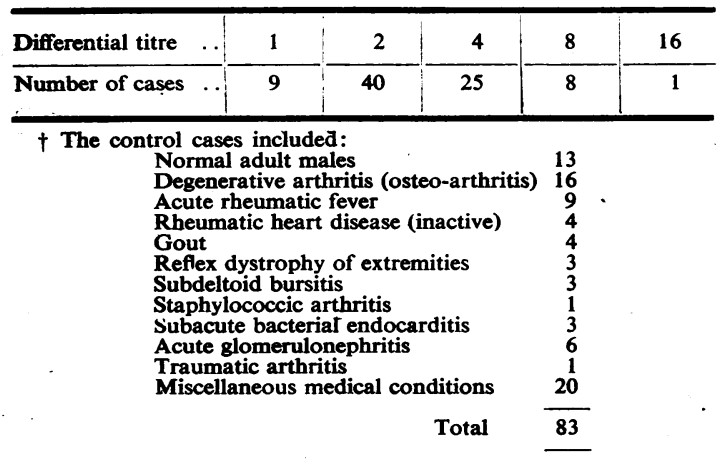

* These strains were given to us by Mrs. Miriam Olmstead Lipman of the Presbyterian Hospital, New York City.
TABLE 2

RESULTS OF TESTS. FOR SHEEP-CELL AGGLUTINATIONS IN SERA OF 62 PATIENTS WITH ACTIVE RHEUMATOID ARTHRITIS

\begin{tabular}{|l|l|l|l|l|l|l|l|l|l|l|}
\hline Differential titre & 1 & 2 & 4 & 8 & 16 & 32 & 64 & 128 & 256 & 512 or higher \\
\hline Number of cases & 4 & 7 & 7 & 10 & 8 & 8 & 7 & 5 & 3 & 3 \\
\hline
\end{tabular}

TABLE 3

RESULTS OF TESTS FOR AGGLUTININS FOR GROUP A HAEMOLYTIC STREPTOCOCCI AND FOR SENSITIZED SHEEP CELLS IN SERA OF 51 PATIENTS WITH RHEUMATOID ARTHRITIS

\begin{tabular}{c|c|c}
\hline H.S. Agglutinins & Sensitized Sheep Cells & $\%$ \\
\hline Positive & Positive & $39 \cdot 2$ \\
Positive & Negative & 13.7 \\
Negative & Positive & 15.6 \\
Negative & Negative & 31.4 \\
\hline
\end{tabular}

and cultures for use in the test were incubated overnight (fifteen hours) in bactopeptone broth. Living cultures were used in the test, and these were incubated at $55^{\circ} \mathrm{C}$. for one hour, and read the following morning for agglutination after refrigeration overnight. A positive test for the purposes of this paper consists of a $2+$ agglutination against all three types at a $1: 20$ dilution and a 2+ agglutination of 1 : 160 against at least one of the types. $\dagger$

\section{Results}

The distribution of the differential titres of the 83 control patients is shown in Table 1. With the exception of one patient, who had subacute bacterial endocarditis and active rheumatic carditis, and whose differential titre was 16 , all sera gave a titre of 8 or less. In this report, therefore, a differential titre of 16 or higher is considered a positive test.

Sixty-two patients with active rheumatoid arthritis are included in this series. The distribution of their differential titres is shown in Table 2. The term " active" as used in this study implies signs of an active process in a joint as indicated by swelling, warmth, and tenderness. Of these patients, 34 , or 55 per cent., had a differential titre of 16 or higher, and 28 patients, or 45 per cent., had a titre of 8 or less. The haemolytic streptococcus agglutination test was done on the sera of 51 of these 62 patients. The relation of the results of one test to the other is shown in Table 3. It will be noted that 54.8 per cent. had a positive sheep-cell agglutination test, while 52.9 per cent. had a positive haemolytic streptococcus-agglutination titre. In 39.2 per cent. both tests were positive; in 15.6 per cent. the sheep-cell agglutination test was

$\dagger$ For further information concerning this test, consult the paper by Nicholls and Stainsby (1931), Dawson and others (1932), McEwen and others (1936), and Boots and others (1949, in the press). 
positive and the haemolytic streptococcus agglutination test negative ; in 13.7 per cent. the sheep-cell agglutination test was negative and the haemolytic streptococcus agglutination test positive. In 31.4 per cent both tests were negative.

The relation of the duration of disease to the incidence of a positive sheep-cell agglutination test is shown in the Figure. There is a rising incidence of positive tests from 25 per cent. of cases of less than one year's duration to 78 per cent. of cases with a duration of sixteen years or longer.

In this group of patients with active rheumatoid arthritis, there were 3 with a normal erythrocyte sedimentation rate and a positive sheep erythrocyte agglutination test ; while conversely the vast majority of patients with differential titres in the normal range had an accelerated erythrocyte sedimentation rate. Thus no correlation can be drawn between these two tests.

Twenty patients in this series had inactive rheumatoid arthritis. Of this group, 6 , or 30 per cent., had a differential titre of 16 or higher. In 17 of the 20 patients both the haemolytic streptococcus agglutination test and the sheep-cell agglutination test were done. Five of these 17 patients, or 29 per cent., had a positive sheep-cell agglutination test, while 7 , or 41 per cent., had a positive haemolytic streptococcus agglutination test. All the five patients with a positive sheep-cell agglutination titre had a positive haemolytic streptococcus agglutination titre.

In the group of patients with rheumatoid arthritis there were 13 with subcutaneous nodules. Of these 13 patients, 7 , or 54 per cent., had a differential titre of 16 or higher ; of the 12 patients in this group whose sera were analysed for haemolytic streptococcus agglutinins, 9 , or 75 per cent., gave a positive test.

There were 9 cases of Marie-Strümpell spondylitis. Two patients, both of whom had involvement of at least one peripheral joint, had titres of 16 . In the remaining 7 patients the titres were 8 or less. There were two cases of psoriatic arthritis and one case of Felty's syndrome; all three had a differential titre of 8 or less.

\section{Summary}

The sheep erythrocyte agglutination test was found to be positive in 55 per cent. of sixty-two patients with active rheumatoid arthritis and in
30 per cent. of twenty patients with inactive rheumatoid arthritis. There was a close but not an exact correlation with the haemolytic streptococcus agglutination titres. The incidence of elevated differential titres increased as the duration of the disease increased. There appeared to be no significant relationship between titre and the presence of subcutaneous nodules. In the nonrheumatoid control group of 83 sera, only one had a differential titre of 16. All the others were below this value.

We wish to acknowledge the technical assistance of Mrs. Clarice Illes and Miss Lotte Weilheimer in performing the serologic tests.

\section{REFERENCES}

Boots, R. H., Lipman, M. O., Coss, J. A., and Ragan, C. (in the press). Transactions of the Seventh International Congress on Rheumatic Diseases. Saunders. Philadelphia.

Dawson, M. H., Olmstead, M., and Boots, R. H. (1932). J. Immunol., 23, 187 and 205.

Jawetz, E., and Hook, E. V. (1949). Proc. Soc. exp. Biol. N.Y., 70, 650.

McEwen, C., Bunim, J. J., and Alexander, R. C. (1936). J. Lab. clin. Med., 21, 465.

Nicholls, E. E., and Stainsby, W. J. (1931). J. clin. Invest., 10, 323.

Rose, H. M., Ragan, C., Pearce, E., and Lipman, M. O. (1948). Proc. Soc. exp. Biol. N.Y., 68, 1.

Sulkin, S. E., Pike, R. M., and Coggeshall, H. C. (1949). Proc. Soc. exp. Biol. N.Y., 70, 475.

\section{Epreuve d'Agglutination Différentielle des Erythrocytes du Mouton dans l'Arthrite Rhumatismale}

\section{RÉSUMÉ}

L'épreuve d'agglutination des érythrocytes du mouton fut positive dans 55 pour cent des 62 cas d'arthrite rhumatismale active et dans 30 pour cent des 20 cas d'arthrite rhumatismale inactive. Il y avait un rapport étroit mais pas exact aux titres d'agglutination causés par le streptocoque hémolytique. La fréquence des titres différentiels élevés augmentait au fur et à mesure que la maladie se prolongeait. Il semble qu'il n'y avait aucun rapport significatif entre les titres et la présence des nodules sous-cutanés. Dans le groupe témoin nonrhumatismal de 82 sérums, un seulement avait le titre différentiel de 16 ; chez tous les autres celui-ci était inférieur. 